\title{
Téoros
}

Revue de recherche en tourisme

\section{The Role of the State in the Development of Tourism in South America}

\section{Regina G. Schlüter}

Volume 13, numéro 2, été 1994

Regards sur le tourisme dans les pays en développement

URI : https://id.erudit.org/iderudit/1077760ar

DOI : https://doi.org/10.7202/1077760ar

Aller au sommaire du numéro

Éditeur(s)

Université du Québec à Montréal

ISSN

0712-8657 (imprimé)

1923-2705 (numérique)

Découvrir la revue

Citer cet article

Schlüter, R. G. (1994). The Role of the State in the Development of Tourism in South America. Téoros, 13(2), 25-28. https://doi.org/10.7202/1077760ar d'utilisation que vous pouvez consulter en ligne.

https://apropos.erudit.org/fr/usagers/politique-dutilisation/ 


\title{
The Role of the State in the Development of Tourism in South America
}

\author{
Regina G. Schlüter*
}

$\square$

Tourism was already used as a tool to achieve regional development in Latin America in the 30 's. The small village of San Carlos de Bariloche, Argentina, located in a region with a very low population density and continuous boundary problems, was to become the permanent home of a high number of settlers. Nevertheless, it was not until after World War II was over that all Latin American countries tried to turn tourism into a passport to national development - development meaning a social and economic transformation process that would take them from poverty and underdevelopment to welfare and modernism.

The economic model in force as of 1955 was the developmental model outlined by CEPAL (Economic Commission for Latin America). According to said model, Latin American countries should make all possible efforts in order to move from the production of primary goods into the industrialization stage $\mathrm{e}^{(1)}$. In order to achieve this aim it was necessary to develop both the industry and the services sector, which demanded large investments and lead the State to play a predominant role.

\section{The State's Intervention in Tourism Development}

In spite of the efforts made by Latin American governments to solve the problems that prevented them from achieving social and economic growth, by the late fifties the region had only reached industrialization through import substitution, while the countries' economies and technology remained dependent upon the First World.

At the Presidents' Meeting that took place in 1961 in Punta del Este (Uruguay), it was concluded that development would never be achieved by spontaneous evolution and therefore had to be planned by the government ${ }^{(2)}$. In thelatesixtiesandearly seventies, almost every country had its own planning. office at a national or state/provincial level.

\footnotetext{
Dr. Regina G. Schlüter is Director of the Centro de Investigaciones y Estudios Turisticos (CIET) of Buenos Aires, Argentina.
}

The governments tried to stimulate the big private enterprises to invest in their coun- tries. However, when thiswasnot achieved, said investments were taken over by the State. The Latin American countries also resorted to foreign financial aid granted by international agencies such as the World Bank, the Organization of American States, thePNUD(United Nations Development Programme), the Interamerican Development Bank, etc.

The progress achieved by Spain was an example of development through tourism which made government officials think that the same results might be achieved in Latin America by turning different tourism resortsintoresorts destinations adapted to the needs of the major consumer markets. While the aims of tourism within the framework of national development were of an economic, social, political and cultural nature, in practice it was the economic aim which prevailed.

In the economic area, tourism was to promote foreign exchange earnings, to allow for the redistribution of income and to achieve the development of economically depressed areas. In the political area, on the other hand, tourism had to be able to transmit a positive image of a country abroad and reinforce its national sovereignty. Finally, as far as the social and cultural areas were concerned, tourism was intended tocreate new jobs, to preserve the national wealth and promote the education and recreation of the resident population.

\section{The Role of the National Tourism Offices}

The States implemented their decision to use tourism as a tool to achieve development through the creation of national tourism offices (NTO). Their structure and functions varied among the different countries.

The NTOs are governmental agencies that work in the tourism area at a national level. Their main aim is to promote the general growth of tourism in order to help 
a community meet its economic and social goals.

Acoording the Acerenza ${ }^{(6)}$, Latin American NTOs have a public nature and are either centralized or decentralized.

Centralized NTOs are part of the public sector's structure and have a different status in each country (ministry, state secretariat, etc.). They take part in the drafting of general policies related to a country's economic and social development but, as any public agency, are subject to the obstacles posed by the administrative bureaucracy.

Decentralized NTOs are under the authority of a State's department but have technical and administrative autonomy. Their range ofaction is set by Law and they only implement policies set forth by the departments to which they report. In Latin America, their structures range among the following models :

- Tourism Commission : it is a non profit organization and its existence is limited in time as its aim is usually to promote tourism.

- Tourism Institute : it has a wider range of functions as it not only promotes tourism but also fosters its development.

- Tourism Enterprise : it performs the same functions as the Tourism Insttute, but does so for the sake of profit.

- Tourism Corporation : its functions are similar to those of the Enterprise, but it is entitled to make investments and to create incentives for the development of tourism.

The NTOs have two key tasks : to open new markets and to create new products. Some of their basic functions, therefore are related to the achievement of such aims. It is their function to formulate tourism policies, plan for tourism resorts, carry out marketing and promotion activities, create incentives for investment, monitor the companies rendering services in the tourism sector, etc. The aforementioned basic functions change in the course of time in order to meet the new requirements.

\section{Government Intervention : National Experiences}

During the first decades after World War II South America tried to foster the devel- opment of tourism. It is then when the policy-making bodies were set up.

Colombia created the National Tourism Corporation in 1969, and as there was a need for foreign currency the Government created incentives for international tourism. A report whose title was Base and Strategies for the Tourim Sector was prepared in 1971. According to such report the priorities are related to the creation of jobs, the redistribution of income, the achievement of regional and urban development and the generation of foreign currency. Other plans issued later on still consider tourism as a tool to earn foreign currency and create jobs, and as means to bring about a redistribution of income ${ }^{(4)}$.

The Government basically devotes itself to study the tourism offer and to promote the country as an attractive destination in the main generating world markets, putting specialemphasis on the Caribbean beaches and the Island of San Andrés.

The first systematic efforts to develop the tourism area in Venezuela were launched by the government in 1970. In 1973 a law was passed to create the Venezuelan Tourism Corporation, an independent institute whose role was toencourage, plan, develop and coordinate the tourism activities in the country. In practice, instead of concentrating on its main function, i.e. being the policy-making body in the area of tourism, it very often was forced to grant guarantees for private investors and to take over, run, and manage hotels, funicular railways and inns ${ }^{(5)}$.

Due to the boom of nature oriented tourism the National Parks Administration has been able to make its voice heard regarding the decisions related to the development of tourism in Venezuela. At present Venezuela is trying to get an important share of the Caribbean-aimed tourism, therefore the State is making great endeavors to develop and promote the sun and beach tourism, especially at the Isla de Margarita.

Ecuador became internationally known through the Galapagos Islands National Park, first described by Charles Darwin and which is now part of UNESCO's list of the World's Natural Heritage. However, the country has some other important touristdestinations such as the city of Quito and the beaches on the Pacific. A national tourism office was created in 1974 in order to promote the growth of the tourism sector. Its functions included setting rules and regulations and monitoring the companies rendering services in the tourism sector; promoting the country in the main generating countries and fostering investments in the tourism sector ${ }^{(6)}$.

The Ministry of Information and Tourism was created in 1993 due to the need to protect delicate ecosystems which had a high tourism potential. Such Ministry had decision making powers in matters related to the management of protected areas $($ )

In Peru, as in most other countries in the region, government intervention is usually limited the control of the companies rendering services and to activities which promote the tourism destinations. As regards tourism planning, in 1969 and heeding a suggestion of the United Nations Development Programme (UNDP), the Peruvian government created a special committee which was to coordinate and supervise the cultural and tourism plan called COPESCO Project. This project is now in its second stage. Its aim is expanding agriculture, the baseeconomy of the CuzcoPuno region, and protecting the Inca archacological sites with the assistance of UNESCO's experts. Protection is focused on the Machu Pichu ruins discowered by Hiram Bingham in 1911.

In 1975 Chile created the National Tourism Service (SERNATUR), a functionally decentralized agency. Its activities were basically directed towards raising foreign currency, fostering investments, creating jobs, promoting the exploitation of tourism attractions and resources, fostering domestic tourism and creating a positive image of the country overseas.

In a report issued in $1984^{\left({ }^{\circ}\right)}$ (SERNATUR) pointsout that it is the government's role in its capacity of policy-making authority, to make everybody become aware of the importance of the tourist phenomenon and realize the need to having a positive attitude regarding the benefits and requirements deriving from this activity. The government's role should not be limited to the activities of the official tourism agency. Its commitment should be reflected in the various social, economic and cultural policies followed by the government as a whole.

In Argentina, the National Parks Adminisuration, an autarchic body created in 1934 , 
marked the beginning of governmental intervention in the development of tourism. The first endeavour of such body was to turn the small city of San Carlos de Bariloche - the only inhabited area in the Nahuel Huaps National Park - into a tourism center which was to cater for international demand and for domestic high class tourists. The government's aim was to achicve economic growth and regional development, to populate the Patagonia which was almost uninhabited and to strenghten the weak sovereignty in the area. In order to protect nature through tourism several national parks werecreated in areas of great beauty. The plan included the development of villages offering high level services to the tourists within such national parks.

In 1943 the Tourism Administration was included within the structure of the $\mathrm{Na}$ tional Parks Administration. It was part of such Administration for a very short spell after which it swayed erratically within the national administrative structure. In 1958 Congress passed the first (and only) $\mathrm{Na}$ tional Tourism Law which established the role of the National Tourism Agency. Such agency was to carry out works of tourist interest, select tourism areas, promote the country as a tourism destination, monitor the companies rendering tourism services, take the necessarysteps before the authorities to remove all obstacles hindering the entrance of tourists, etc.

The status of the National Tourism Agency changed several times within the administrative organization chart. At present the National Tourism Secretariat (SPCTUR) reports directly to the $\mathrm{Na}$ tional Presidency.

Although in Argentina all the provinces have local tourism agencies, they usually limit their role to monitor the companies rendering services within their jurisdiction and they very seldom advertise the prowinces' attractions. The province of Chubut is an exception to this rule. In 1967 it developed a system of marine fauna reservations on the Patagonia's coasts and in 1973 it also created a geological reservation (petrified woods). During the 1968 1979 period the National Tourism Agency supplied over $59 \%$ of the resources invested in the province as it considered the fauna reservations an international tourism attraction $^{(9)}$.
In Brazil, the government's intervention in the tourism area dates back to 1966 when the Brazilian Government Tourism Enterprise (FMBRATUR) and the National Tourism Committee (CNTUR) were set up, although their functions were only defined 12 years later ${ }^{(10)}$. Their key role was to protect the natural heritage, promote domestic tourism, raise foreign currency, carry out advertising campaigns, etc. Within its 8511965 sq. km $(3286470$ sq. miles) the countryoffers a wide range of tourist attractions. Nevertheless, emphasis was put on the development of two products: sun and beach, and ecotourism or nature based tourism. The TURIS project was one of the most important projects in this area. It was launched in 1972-1973 and aimed at developing achain of seaside resorts on the Atlantic const, from Rio de Janeiro to Santos, for both domesticand international tourism. These resorts attracted mainly tourists from Argentina who also visited the beaches that stretched from Santos to Porto Alcgre. Later on, additional developments were carried out in Northeast Brazil, where Dutch, Portuguese and African cultural remains combine with hedonism at vacation resorts. These developments succeeded in making the country more attractive for tourists from the USA and Europe.

In Northeast Brazil, the Bahia State Government is currently building the necessary infrastructure in order to attract investors and developers to create the ForteSauipe Tourism Center, located in a protected area near Salvador ${ }^{(11)}$. In the field of eootourism, EMBRATUR and the Ama= zonian Tourism Enterprise(FMANTUR) are carrying out joint feasibility studies for 38 projects $^{(i n)}$.

The remaining NTOs in South America are the Ministry of Tourism in Uruguay, the Bolivian Tourism Institute, and the General Tourism Directorate in Paraguay. In addition to their individual efforts to promote tourism in their territories, several countries requested technical assistance from intergovernmental agencies, especially the OAS, in order to create integrated tourism circuits such as the Andean Circuit for Tourism Integration, the Circuit of the Jesuitical Missions in Paraguay, Brazil and Argentina, the Lakes Tourism Circuit in Argentina and Chile, the Tourism Integration of the Amazonia (Bolivia, Brazil, Colombia, Ecuador, Guyana, Peru, Surinam andVenezuela). However, due to the difficulties involved in the removal of customs and migration barriers and to the lack of a true political will to implement them, such projects have not become effective yet.

Within MERCOSUR, the NTOs of the member countries of said common market - Argentina, Brazil, Paraguay and Uruguay - signed in 1991 an agreement in order to increase the tourist flow towards the region.

\section{Consequences of Government Intervention in the Tourism Area}

The statistics show an important increase in tourism flows towards South America. However, as a whole the region only accounted for $10,07 \%$ of the total number of arrivals to the American continent and for 2,16 of the total number of arrivals worldwide. As regards tourism receipts, South America got a 8,95\% share of the American Continent's market and a 2,47 $\%$ share of the world market ${ }^{(13)}$.

The main characteristic of South American tourism is the high participation of the region - $80 \%$ of the arrivals stem from other countries in the region. As it can be seen in the following chart, Argentina, Uruguay and Brazil are the main destinations and in both cases their main markets are the neighboring countries (between 70 and $80 \%$ ). The fluctuations in the arrivals are related to the exchange rates and the price levels.

With the exception of Mexico and the Dominican Republic, where the governments played and active role whereby they carried out the investments which were necessary for the development of integrated tourism centers, nothing similar was done in the remaining South American countries during the second half of the twentieth century.

This was not due to a lack of interest, but rather to the fact that there was no assurance as regards the profitability of the investments as the region as a whole was not able to offer the product which was mass consumed by the large generating countries (sun and beach + high temperatures all year round).

Due to domestic problems Colombia and Venezuela, the only two countries which would have been able to take advantage of tourism flows towards the Caribbean, be- 
gan to compete in the market when other destinations in the area were already consolidated.

In a few cases the Governments participated in the construction and management of hotels and recreational facilities. Nevertheless, whatever their status and the role assigned to them the NTOs' priority was usually to promote what they considered their countries' main destinations in the extraregional markets which were very sensitive to the security. As there are no pre/post advertising campaign figures, the results of such promotion efforts can not be elearly assessed. The international mass media very often stressed socioeconomic and political aspects which spoiled the image of the countries involved (guerrilla wars, killing of street children, military repression, hyperinflation, diseases such as cholera, human rights violation, etc) and thus totally tarnished all advertising campaigns designod to show the merits of the lost paradises. This accounts for the fact that only $0,9 \%$ of the trips generated in the USA and Canada, and $1 \%$ of the ones generated in Europe have South America as their destination ${ }^{(14)}$

Most of the national and multinational projects did not go beyond the prefeasibility study stage. However, some of the projects which were carried out, such as the COPESCO Project resulted in an increase in the number of hotel beds and in an improved infrastructure. In other cases, a tourism destination benefited from the infrastructure developed for some other reasons. Such is the case of the fauna reservations in Chubut which took advantage of the infrastructure developed for an aluminium processing plant. The same happened in the south of Chile where the Southern Highway, which was built by the government due to geopolitical reasons, paved the way for tourism - mainly adventure tourism - to the south of the country.

As regards the extraregional market, the South American countries found a niche for their products in the current trend towards nature based tourism observed in industrialized countries.

\section{Final Comment}

In Latin America, the governments' intervention in the economy gave origin to huge debts with the International Monetary Fund and with the private banking

Table

South America: Tourist Arrivals and Tourism Receipts by Country, 1991

\begin{tabular}{lcccc}
\hline Country & $\begin{array}{c}\text { Arrivals } \\
(000)\end{array}$ & $\begin{array}{c}\text { Share of } \\
\text { Americas } \\
\text { total (\%) }\end{array}$ & $\begin{array}{c}\text { Receipts } \\
(000 \text { 000 USS) }\end{array}$ & $\begin{array}{c}\text { Share of } \\
\text { Americas } \\
\text { total (\%) }\end{array}$ \\
\hline Argentina & 2870 & 2,94 & 2336 & 3,24 \\
Bolivia & 221 & 0,23 & 90 & 0,12 \\
Brazil & 1352 & 1,39 & 1559 & 2,16 \\
Chile & 1349 & 1,38 & 700 & 0,97 \\
Colombia & 857 & 0,88 & 410 & 0,57 \\
Ecuador & 365 & 0,37 & 189 & 0,26 \\
Guyana & 73 & 0,07 & 30 & 0,04 \\
Paraguay & 361 & 0,37 & 145 & 0,20 \\
Peru & 232 & 0,24 & 277 & 0,38 \\
Suriname & 30 & 0,03 & 11 & 0,02 \\
Uruguay & 1510 & 1,55 & 333 & 0,46 \\
Venezucla & 598 & 0,61 & 365 & 0,51 \\
\hline
\end{tabular}

Source: WTO, 1993.

sector of developed countries. Towards the end of the eighties and the beginning of the nineties a serious crisis brokeout and as a result of this several plans of economic downsizing were implemented. Among other steps, such plans called the privatization of state owned companies, including those companies considered to be related to donestic security: air transport, telecommunications, energy, etc.

The tourism sectors were not deeply affected by the failure of the governmental intervention model, as the governments' participation in the tourism sector was usually limited to pompous well meant statementsand to the development of some advertising campaigns which never went beyond the printing of some leaflets and brochures and the attendance of international fairs.

In spite of the various positions the NTOs occupied in the organization charts of their countries, their heads had little political power and thus did not take part in the major decision making processes.

The privatization programes undertaken by the governments did not affect the $\mathrm{NTOs}$, as the latter did not own or manage any goods. However, an important change took place. Instead of working together with intergovernmental agencies and planning for projects which would never come into effect, the NTOs began to carry out market research studies with foreign technical assistance. Therefore such studies were more likely to become a useful tool which would enable the countries involved in the studies to better capture the large markets.

Although at first sight government intervention does not seem to have contributed to the development of tourism, in practice it has been noticed to have had a positive influence. It focused attention on the importance of tourism and it highlighted to the private sector that there is a valid alternative to the traditional productive activities, which if managed with the proper commercial criteria may become a vitalizing agent for the national and regional economies. $f$

\section{NOTES}

(1) C Lizama Hemandez Desamollo Turistico en Costa Fica, in Desarrollo Turistico de America Costa Aica, in Desarrollo Turistico do
Latina, CESTUA (ed). 1991, pp, 43-49,

(2) A. Schlutter, Social and Cultural Impacts of Tour ism Plans and Programs in Latin America, Centre des Hautes Etudes Touristioues, 1991.

(3) M. Acerenza, Administracion del Turismo Coneeptualizaclon y Organizacion, Editorial Trillas, Mexico, 1991.

(4) C. Kelman and V. Fernandez, Tiempo Libere. Turismo y Sociodad, Universidad Externado de Colombia, 1986

(5) J. Cacere Rampira, La Evolucion /nstituciongl de Activided Turistics en Venezuela (1909-1991) in Estudios y Perspectivas on Turismo, 2, 1993 , Estudios 331.354

(6) E. Boo, Ecotourlent The Potentials and Pitfalls, WWF, Washington, D.C., 1990

(7) C. Vera, It is Nature and Not ON That is Our Mast Important Aespurce, in Proceedings of the 1993 World Congrese on Adventure Travel and EcoTourism Manaus.

(8) SERNATUR Conciencia Turistica, Boletin Teenico, no 2. March 1984.

(9) R. Schlüter, Turismo $\mathrm{Y}$ Areas Protegidas an Argentina, CIET, Buenos Aires, 1990.

(10) M. Barretto, Planejamento E Organizacáo om Turismo, Papirus, Sao Paulo, 1991.

11) E Pina Mendonca, An Integrated Tourism Center, Fort-Sauipe, Paper presented at the IFTI. Jerusalem, 1993

(12) D. Auschmann, Ecological Towism in Brazil in Tour ism Management, 13, pp. 125-128.

(13) World Tourism Organization (WTO), Yearbook of Tourtsm Statistica, Madrid, 1993.

(14) A. Schlitter Pertil de Los Mercados Turisticos de Amenca Latins, in Rovista Latinoamer leana de Turlsmo, 1, 1991, pp. 171-187 